\title{
Pedestrian behavior patterns in relation to the quality of public space on the edge of the Historic Center of Cuenca-Ecuador
}

\author{
Patrones de comportamiento peatonal en relación a la calidad del espacio \\ público en el borde del Centro Histórico de Cuenca-Ecuador
}

\author{
Karina Alexandra Cherrez Rodas. ${ }^{1}$, Myrian Alexandra Larco Benítez. ${ }^{2}$ \& Fredy Rafael
} Llulluna Llumiquinga. ${ }^{3}$

Recibido: 19-11-2020 / Revisado: 16-12-2020 /Aceptado: 12-01-2021/ Publicado: 05-02-2021

\begin{abstract}
.
DOI: https://doi.org/10.33262/concienciadigital.v4i1.1.1553

Introduction. Public space is important in the architecture of cities; however, since the 20th century, it has lost its prominence. Also, it has presented a decrease in the performance of social activities due to the appearance of certain architectural typologies. In this sense, the study of users of public space allows us to understand their needs and diagnose future urban interventions. Cuenca was declared as Cultural Heritage Site by UNESCO. "El Barranco" which is the edge of the Historical Center of Cuenca and a major connector with the new planning area, is an elementary setting for social relations. Objective. Determine the influence of the quality of public space on pedestrians' behavior patterns. Methodology. The

\footnotetext{
${ }^{1}$ Universidad Regional Amazónica Ikiam, Facultad de Ciencias Socioambientales, Tena, Ecuador. karina.cherrez@ikiam.edu.ec, https://orcid.org/0000-0001-6330-3955

${ }^{2}$ Universidad Regional Amazónica Ikiam, Facultad de Ciencias Socioambientales, Tena, Ecuador. myrian.larco@ikiam.edu.ec, https://orcid.org/0000-0002-1846-8440

${ }^{3}$ Universidad Regional Amazónica Ikiam, Facultad de Ciencias Socioambientales, Tena, Ecuador. fredy.1lulluna@ikiam.edu.ec, https://orcid.org/0000-0001-5981-2394
} 
research was quantitative, descriptive in nature, carrying out each study point of observations of pedestrian dynamics for two weeks and using a data collection form, surveys were applied to 240 users who frequent the stairways and 3337 forms were obtained. Results. Through the study of five strategic points of "El Barranco", it was determined that the quality of its public space is not good enough and this has provoked that the use of its stairways is mostly devoted for everyday activities rather than social ones. There is very little motivation to develop social activities. It was also found that the age group, nationality, and ethnicity influence on the behavior patterns of pedestrians. Of all the pedestrians who pass through the study points, it was determined that only $20 \%$ carry out social activities, $24 \%$ optional activities and $56 \%$ only use them as connection points to their daily activities.

Keywords: Behavior patterns; pedestrian zones; connection points; public space.

\section{Resumen.}

Introducción. El espacio público es importante en la arquitectura de las ciudades; sin embargo, desde el siglo XX ha perdido su protagonismo. Además, se ha dado un descenso en la realización de actividades sociales debido a la aparición de ciertas tipologías arquitectónicas. En este sentido, el estudio de los usuarios en el espacio público permite comprender sus necesidades y diagnosticar futuras intervenciones urbanas. Cuenca fue declarada Patrimonio Cultural de la Humanidad por la UNESCO. "El Barranco" es el borde del Centro Histórico de Cuenca y es un importante conector con la zona de nueva planificación lo que lo convierte en un escenario elemental de relaciones sociales. Objetivo. Determinar la influencia de la calidad del espacio público en los patrones de comportamiento de sus peatones. Metodología. La investigación fue de carácter cuantitativa, de tipo descriptiva realizando cada punto de estudio observaciones de la dinámica peatonal durante dos semanas y mediante una ficha de recolección de datos se aplicaron encuestas a 240 usuarios que frecuentan las escalinatas y se obtuvieron 3337 formularios. Resultados. A través del estudio de cinco puntos estratégicos de "El Barranco" se determinó que la calidad de su espacio público no es buena y esto ha incidido a que sus escalinatas se usen mayormente para actividades necesarias, y que exista muy poca motivación para desarrollar actividades sociales. También se encontró que el grupo etario, la nacionalidad y el grupo étnico influyen en los patrones de comportamiento de los peatones. De todos los peatones que transitan por los puntos de estudio se determinó que solo el 20\% realiza actividades sociales, $24 \%$ actividades opcionales y el $56 \%$ solo los utiliza como puntos de conexión a sus actividades cotidianas.

Palabras claves: Patrones de comportamiento; zonas peatonales; puntos de conexión; espacio público. 


\section{Introduction.}

Throughout history, the importance of public space in the architecture of cities has been evidenced (Gamboa 2002),(Gehl 2014). During the 19th century, the pedestrian played an important role in the design of public spaces. However, in the twentieth century, the automobile emerged as one of the important issues in people's daily lives (Panagopoulos et al. 2018), and caused the city turned into an automated area, a kind of zoned production machine which made it lose the essence of its urban spaces (Gamboa 2002). In this regard (Gamboa 2002) stated "Gradually it is recognized that the old cities have" something" that new neighborhoods and new parts of cities lack of (...), which makes them more livable, pleasant, recognizable and understandable"(p. 17). Based on the ideas previously exposed, it can be recognized the change of a system where the collective prevails over an individualistic system; a system where its main function is movement, because it is not exploring, but it is crossing.

A transcendental factor within the public space is the social dimension. In fact, in the definition of urban space made by Delgado (Delgado 2004) sociability in buildings and plazas was valorized, and heterogeneity of actions and actors were recognized: "The urban, like the city minus its architecture, everything that does not stop or solidify in it. A melted universe (p. 4-5). Also, Gehl (Gehl 2004) in his book "Humanization of Urban Space" classified activities as necessary, optional, and social ones, this allows to make a direct relationship between spatial quality of external areas with the number of social activities that take place in public spaces. In this sense, it can be observed that, in recent decades, there has been a decline in social relationships due to the emergence at a great scale of architectural typologies that generate social segregation and, therefore, the re-placement of certain social encounters.

Additionally, it is important to point out that today's cities have other requirements than cities in the past (Panagopoulos et al. 2018), the challenge is to conceive urban spaces that prioritize social relations in public space and that contribute to the generation of sustainable cities with less vehicular traffic (Soni and Soni 2016). Loss of quality of public space affects cities in different contexts, this has caused a reformulation of public spaces based on the logic of prioritizing pedestrians, and has forced to seek comprehensive planning, especially in highly consolidated areas. Then, a review of previous studies that include diagnoses in intervention areas is very important for its possible application in places that need to improve their public space.

For instance, there is research that allows us to understand the behavior of pedestrians in study areas. One of these is carried out in Kalamaria, Greece, where it was identified that the use of its public space provides security and comfort to its residents. It was also identified that these results are used by the authorities for their management (Panagopoulos et al. 2018). In Ecuador, a reference study is the one carried out (Hermida et al. 2019) where a toolbox 
was built to evaluate the connectivity and comfort of urban banks that allows a comparative visual and numerical analysis in different areas of the same river. In this line, on the research about Indicators of Spatial Chaos in the Context of the Need for Retrofitting Suburbs the authors claim that the retrofitting of suburbs can be accomplished by impacting two dimensions of spatial chaos: limited pedestrian mobility around the place of residence (walkability) and low access to basic services (Mantey and Pokojski 2020). Previous studies on users of public spaces allow us to understand their needs and diagnose urban spaces before the intervention.

Cuenca is a city in the Andean region of Ecuador and since 1999 it was declared a Cultural Heritage of Humanity by the United Nations Educational, Scientific and Cultural Organization (UNESCO). "El Barranco" is the edge of the historic center of Cuenca, it is located on the banks of the Tomebamba River and is a space with unprecedented characteristics due to its landscape, its use, and its meaning for the memory of the people of Cuenca. Also, "El Barranco" acts as a connector between the historic center and the area of new urban planning that has a significant topographic gap.

Under the above, the present investigation aims to determine the influence of the quality of public space in the patterns of behavior of pedestrians through the study of five strategic points of pedestrian connection between the edge of the historic center and the area of replanning urban Cuenca. Therefore, the questions to be answered are: how does the quality of public space influence the behavior of pedestrians on the edge of the historic center of Cuenca? Is the spatial quality of the historic center of Cuenca low? Is there a motivation for pedestrians to carry out social activities on the stairways of "El Barranco"? Do the age group, nationality, and ethnicity influence the use of public space? Is the kind of activity related to the use of the public space of "El Barranco"?

\section{Metodologia.}

Since this research is descriptive in nature, a three-stage methodology is proposed to determine the influence of the quality of public space on the behavior patterns of the inhabitants of the historic center of Cuenca. The stages are as follows:

1. Study area;

2. Data collection to determine the social behavior of the inhabitants of the Historic Center of Cuenca and their perception of the public space;

3. Analysis and results.

\section{Study area}


As mentioned above, "El Barranco" is located in Cuenca, Ecuador. Cuenca is located in the southern part of the Andean mountain range and sits in a valley. Its climate is spring-like all year round and it has a landscape that blends with the built-up scale of the city. According to the Population and Housing Census carried out by the National Institute of Statistics and Censuses (INEC), in 2010 the population density of Cuenca was 4,701.63 inhabitants / km2. In 1999, its historic center was declared a World Heritage Site by UNESCO, and most of the institutional buildings, hotels, restaurants, commercial premises, squares, and churches are located there. Also, it groups a large part of the work, cultural, commercial, and service activities. Its urban morphology presents narrow colonial streets, and its topography is rugged, especially towards the southern end where the Tomebamba river is located (Terraza, Beltrán, and Orbea 2014).

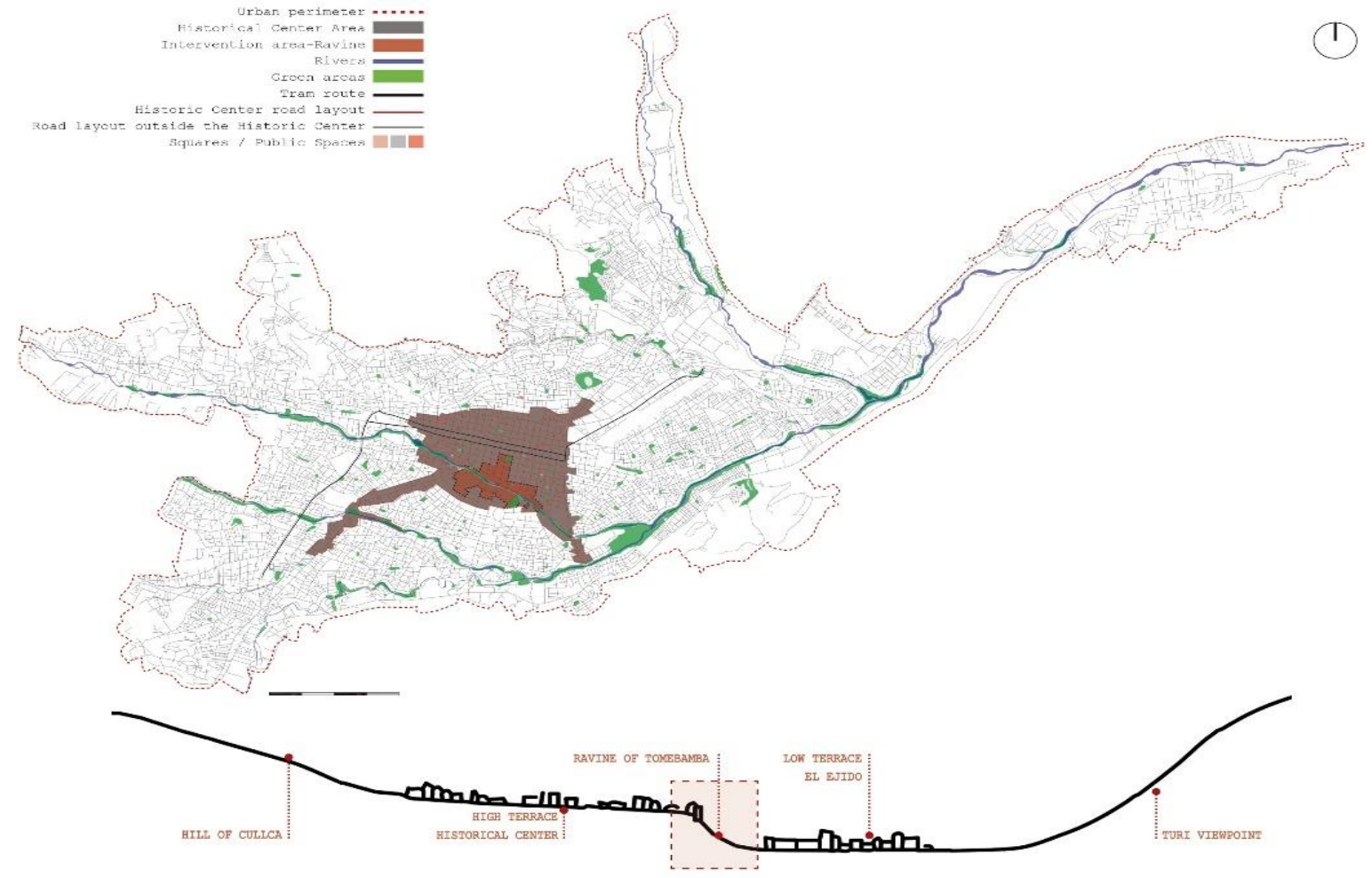

Figure 1. Study area of "El Barranco", Cuenca, Ecuador.

Source: Authors elaboration

The edge of the historic center of Cuenca is known as "El Barranco" which is perceived as a natural boundary between the historic center (Spanish foundation) and the new planning area of "El Ejido". It is built near the Tomebamba river to a height of 20 meters below the upper deck. Its buildings have two facades of the same hierarchy; On one side, the buildings start in the central street, and on the opposite side, they hang down towards the river and are balconied towards the edges of the historic center, which makes them enjoy privileged landscapes. From the "El Vado" bridge to the "Puente Roto" sector there are exterior connectors (connecting stairway) to the two terraces. The study area figure 1 . Therefore, the 
edge of the historic center called "El Barranco" was defined as the study area. Five strategic points were selected because they constitute a space with unique characteristics for the city and its inhabitants. Its location is relevant since it is the transition from the terrace of the historic center, which descends towards the shore of the Tomebamba River, to the area of new urban planning. Furthermore, the archi-tectural complex that makes it up, thanks to its topography, allows pedestrians to have a privileged view. Most of the surrounding streets and places of citizen connections are almost mandatory for transit. Finally in general terms, "El Barranco" is a potential setting for social relations. The five strategic points selected (figure 2):

1. SP 1 - Stairway "El Vado"

2. SP 2 - Stairway "El Centenario"

3. SP 3 - Stairway "Juana de Oro"

4. SP 4 - Stairway "Francisco Sojo Jaramillo"

5. SP 5 - Stairway "Puente Roto"

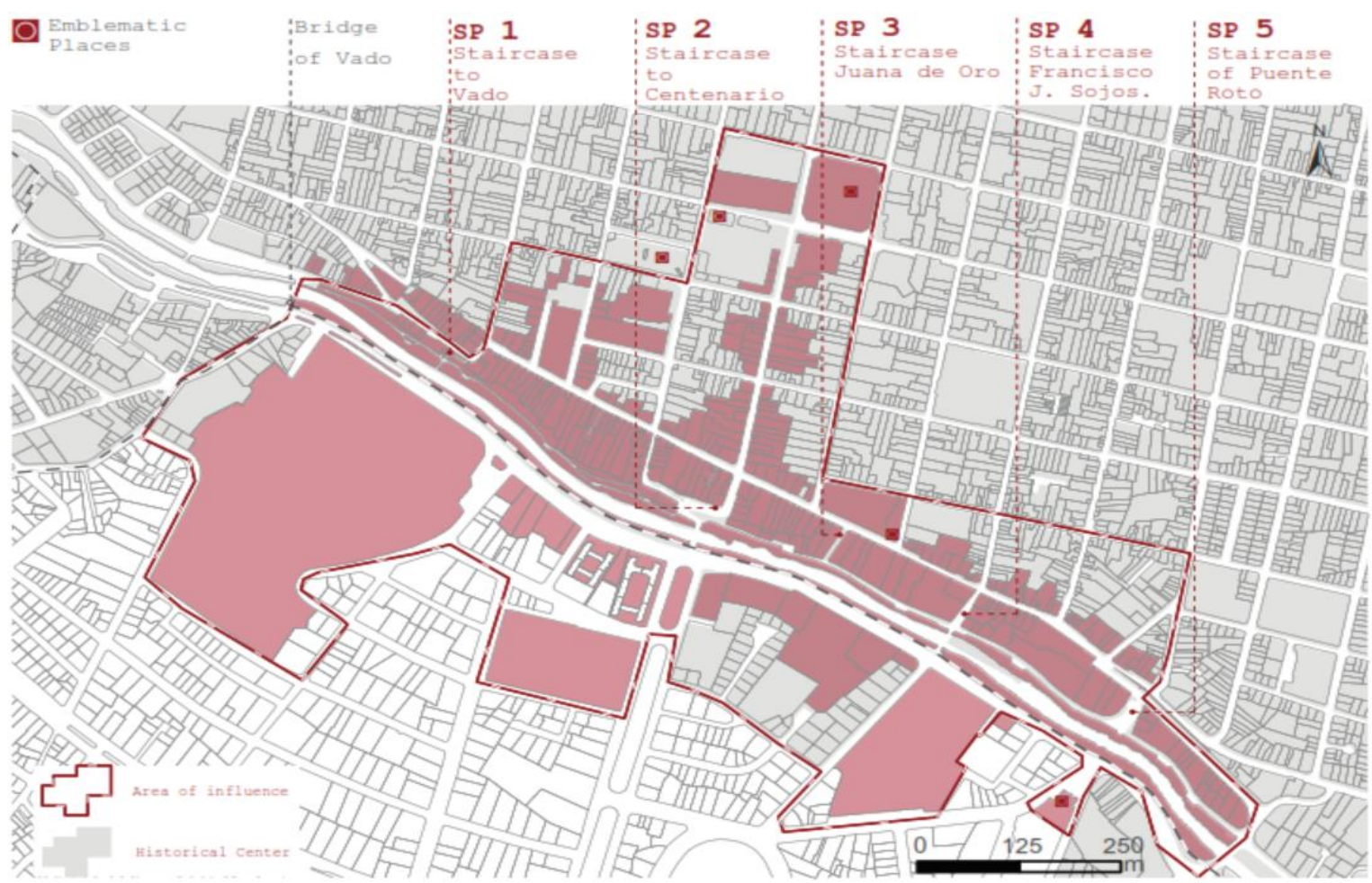

Figure 2. Strategic study points in "El Barranco".

Source: Authors elaboration

The characteristics that describe the peripheral area of the historic center are quite forceful thus some activities in the outer space, in each strategic point of the sector, can be developed actively. The stairs allow the connection of necessary activities between the heritage terrace 
and the contemporary one. It is important to determine which strategic points selected favor social encounters. For this reason, the diagnosis of the current situation of each connection point is carried out through field observation and data collection using specialized software. The selection of strategic points for behavior analyzes patterns is shown below.

SP 1 - Stairway "El Vado

This stairway was built approximately 35 years ago and allows Tarqui Condamine Street to connect with Paseo Tres de Noviembre (pedestrian path). There are 93 steps; and at the end, there is a pedestrian bridge that allows communication with the main entrance of the University of Cuenca. Its area of influence is in the "El Vado" neighborhood, which is one of the most emblematic and traditional ones in the city. In the area of the market 10 de Agosto, there are several buildings of heritage value such as the Arcos house. There are also traditional businesses such as barbershops, toquilla straw hats shops, bronze and tin handcrafted products. Also, the "El Vado" bridge was the entrance to the city in colonial times and connects the upper area of the city with Loja Avenue, where the emblematic San Roque neighborhood is located. In Figure 3, the area of influence, a photograph, and the setting of this strategic point.

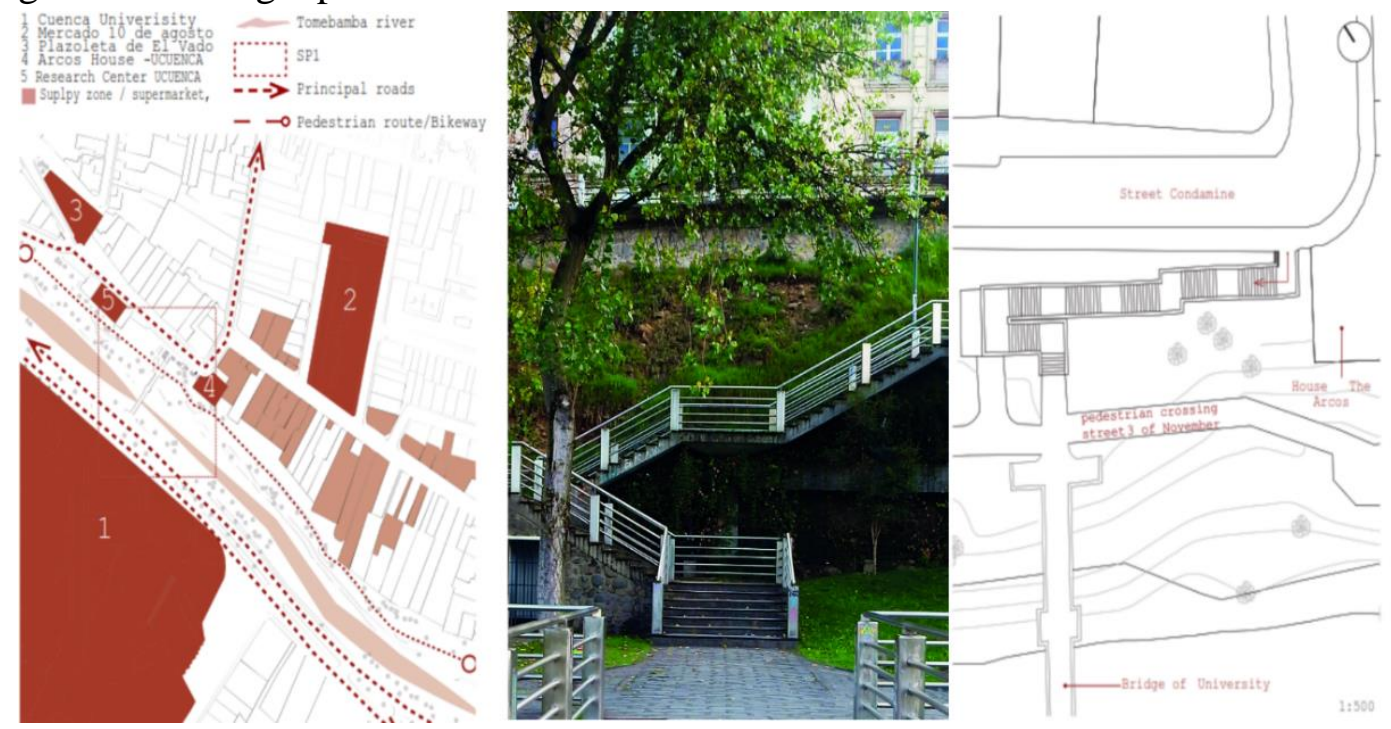

Figure 3. Area of influence, photography, and surroundings of the stairway "El Vado" Source: Authors elaboration

\section{SP 2 - Stairway "El Centenario"}

It has been named after the celebration of the 100 years of the independence of Cuenca since its construction just finished during those days. This stairway consists of 47 steps and allows the connection of the two terraces of the city. This strategic point, which is located at Benigno Malo street, is particular because it reaches Central Park that is just 300 meters away. By crossing its bridge, the Solano Avenue is found where important commercial, banking, 
student institutions are located as well as multi-family homes in height; and the stadium. Finally, this strategic point has an impressive view of the southern part of the city. In figure 4 , the area of influence, a photograph, and the surroundings of this strategic point.

Figure 4. Area of influence, photography, and surroundings of the stairway "El Centenario"

Source: Authors elaboration

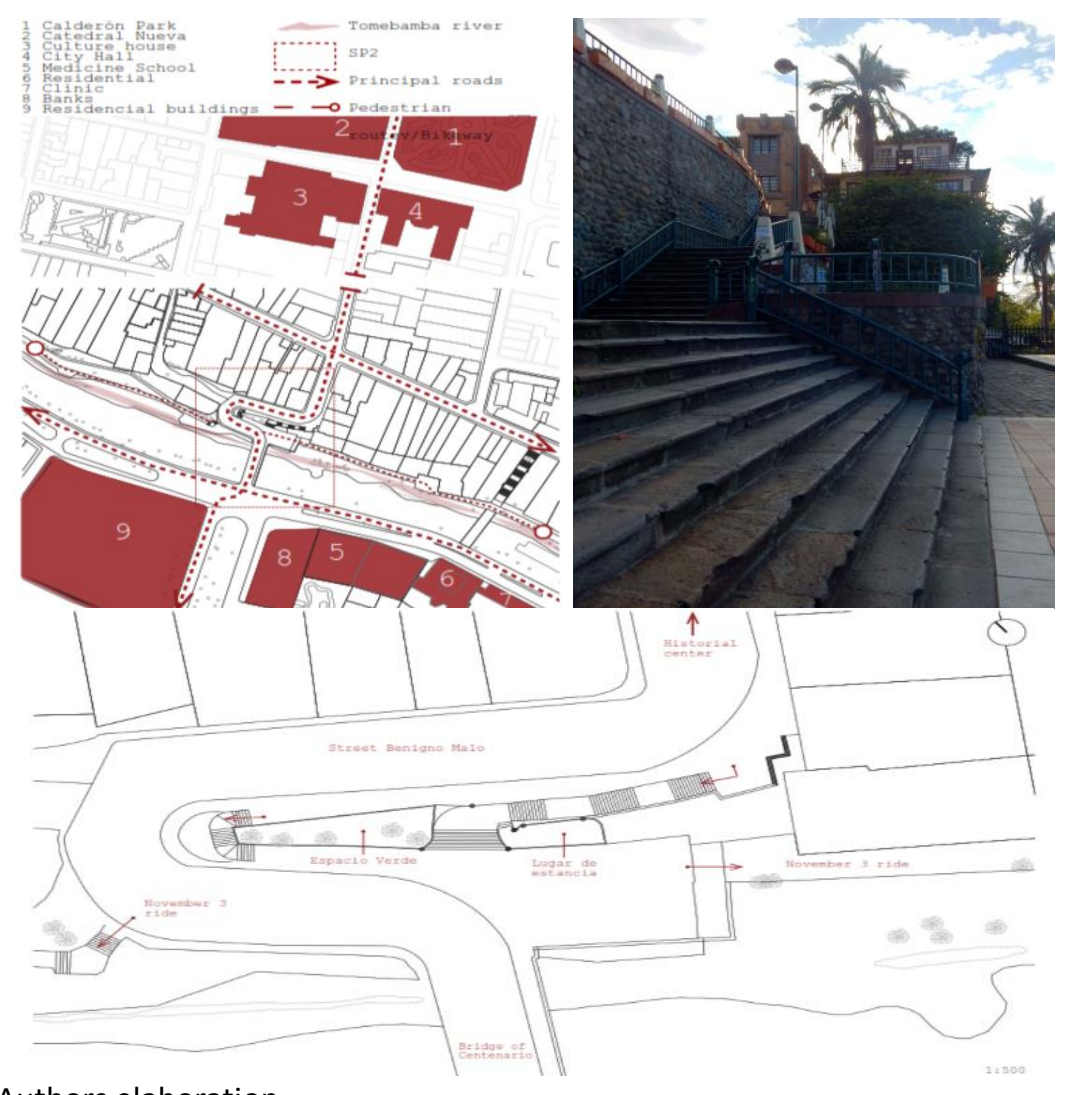

\section{SP 3 - Stairway "Juana de Oro"}

It started as a private service path of one of the adjoining houses and later it was donated to the municipality, which built the stairs eventually. The "Juana de Oro" stairway recovered much of its condition for pedestrians 12 years ago when the hotel that adjoins it finished building on the area, the building occupied half of its area. The current version of this stairway is made up of 77 steps. At the top, there is a tree and the access to the hotel and service areas of surrounding homes. It is also important to mention that, in recent years, its walls were intervened with murals. Figure 5 the area of influence, a photograph, and the surroundings of this strategic point. 


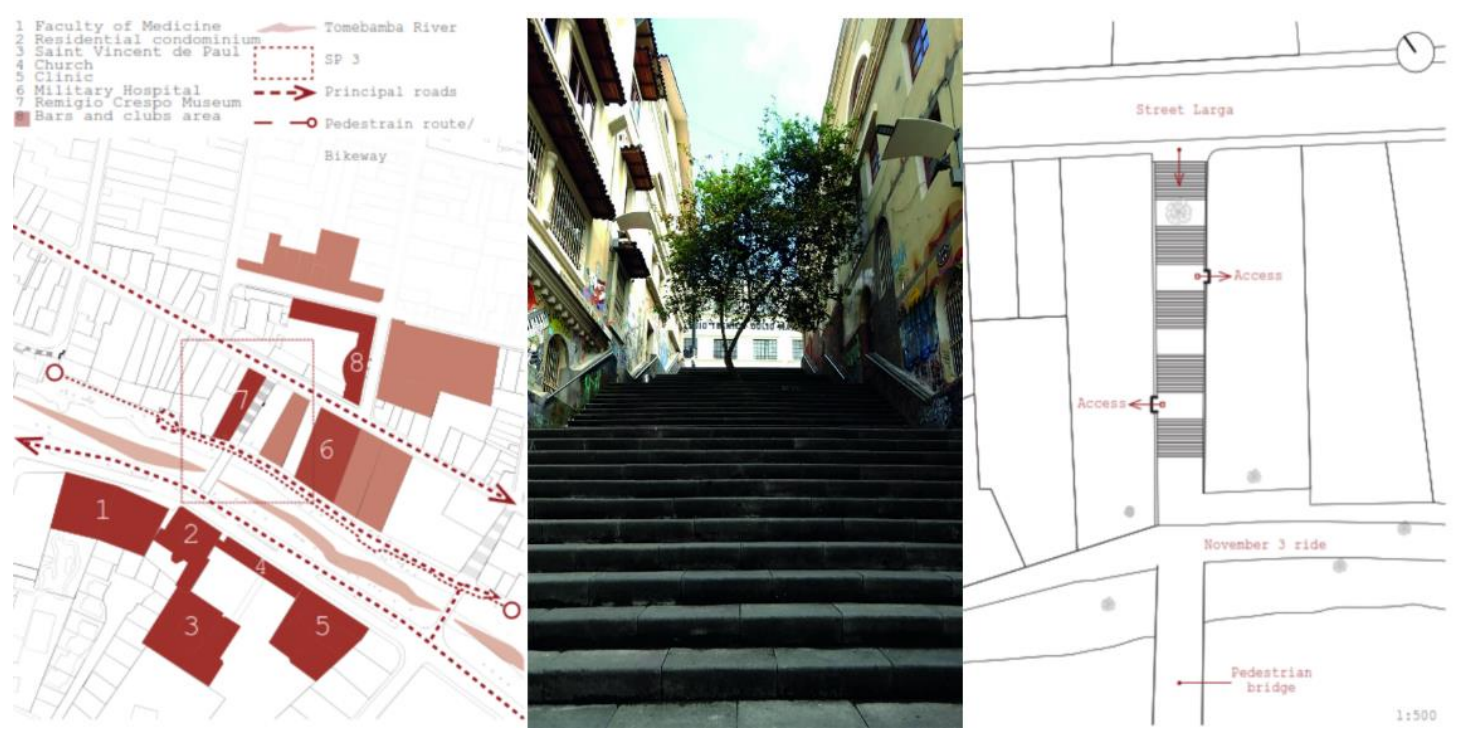

Figure 5. Area of influence, photography, and surroundings of the stairway "Juana de Oro" Source: Authors elaboration

\section{SP 4 - Stairway "Francisco Sojo Jaramillo"}

It connects the historic center with the Parque de la Madre, which is the largest green area near the city center. It adjoins with buildings of heritage value both municipal and private; on its breaks, there are accesses to these properties. Previously, it was made up of lateral green areas and central circulation. Its area of influence is formed by the Remigio Crespo Museum, the Military Hospital, and the Museum of the Faculty of Medi-cine, the Mother Park, and the Inter-American Museum of Popular Arts. Figure 6, the area of influence, a photograph, and the surroundings of this strategic point.

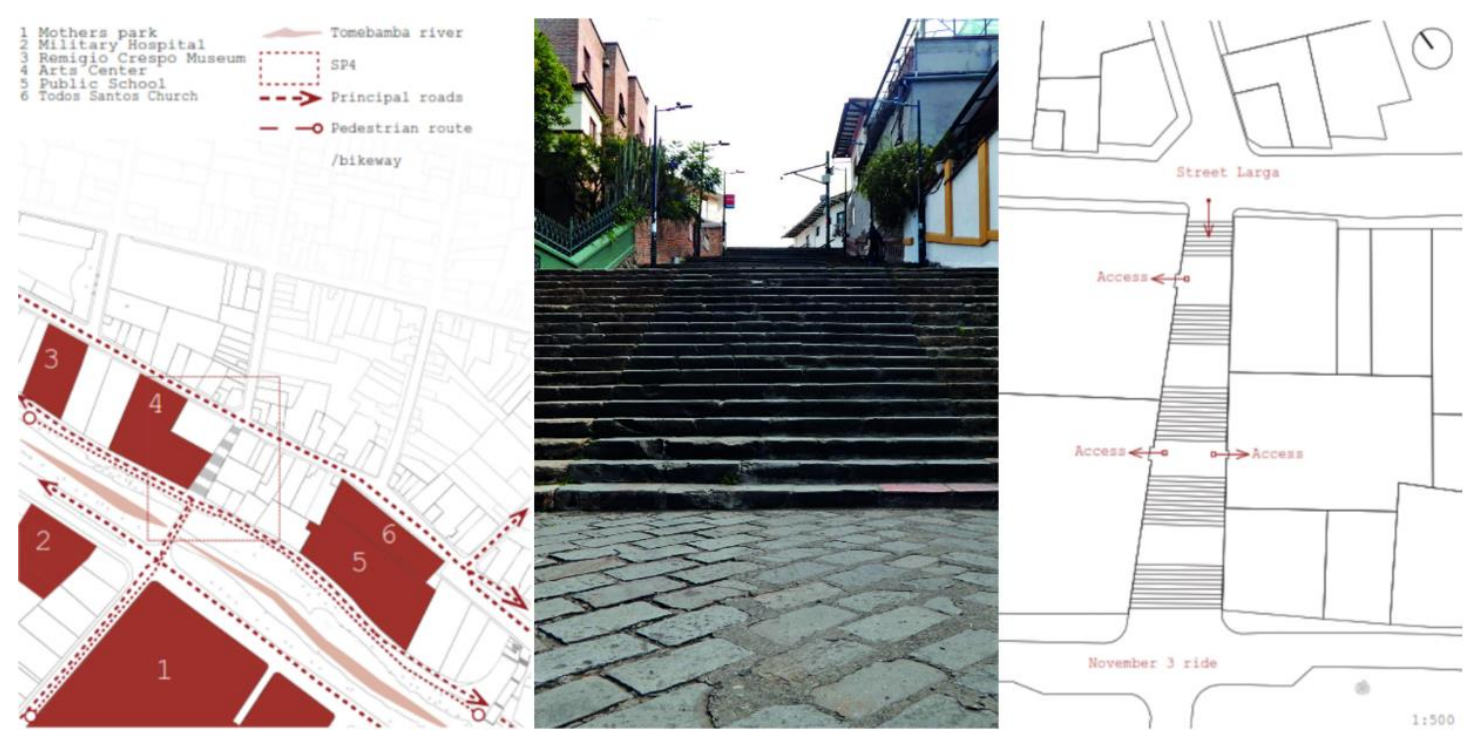

Figure 6. Area of influence, photography, and surroundings of the stairway "Francisco S. Jaramillo" Source: Authors elaboration 
SP 5 - Stairway "Puente Roto"

In 1950, the "Puente of Todos Santos" lost much of its structure after the flood caused by Tomebamba River. However, in recent decades, "El Puente Roto", which is the structure of what was the "Puente de Todos Santos", has become a landmark of the city. It is made up of a truncated bridge and has steps that allow you to communicate with a small square towards the Tres de Noviembre ride. The Church and the ruins of Todos Santos is within its area of influence. Towards the river, you have access to a municipal educational unit that is part of the grounds of the church and the other nearby properties are mostly homes. Figure 7 the area of influence, a photograph, and the surroundings of this strategic point.

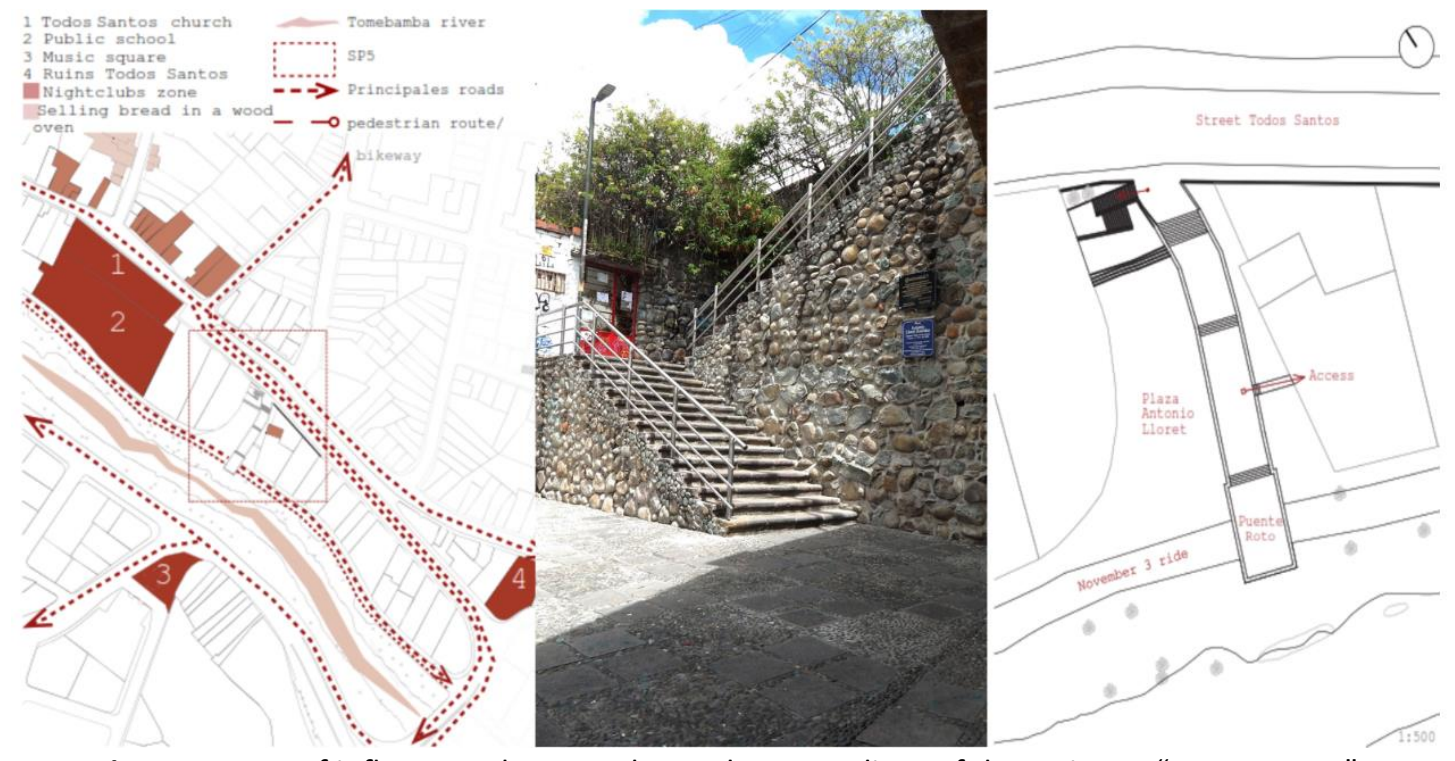

Figure 7. Area of influence, photography, and surroundings of the stairway "Puente Roto" Source: Authors elaboration

\section{Data collection to determine the social behavior of the inhabitants of the historic center of Cuenca and their perception of public space}

\section{Social cohesion in the city}

A distinguishing feature of Cuenca is its people, its culture, and its customs. The Chola Cuencana is the predominant ethnic group in this city. The woman of this ethnic group is mestizo (Indian-Spanish) and is characterized by her colorful and elaborate traditional clothing. Her outfit is made up of a white blouse, a pocket, the skirt, the cloth, and, finally, a toquilla straw hat. The man is characterized by carrying a hat, cashmere pants, shirt, and a wool sweater. Figure 8 the traditional clothing of the Chola Cuencana for women and children. 


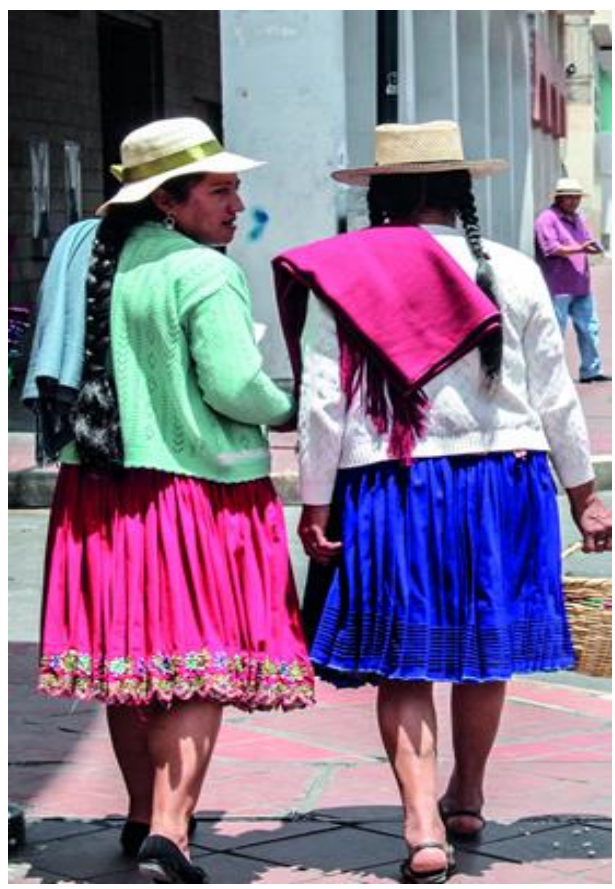

(a)

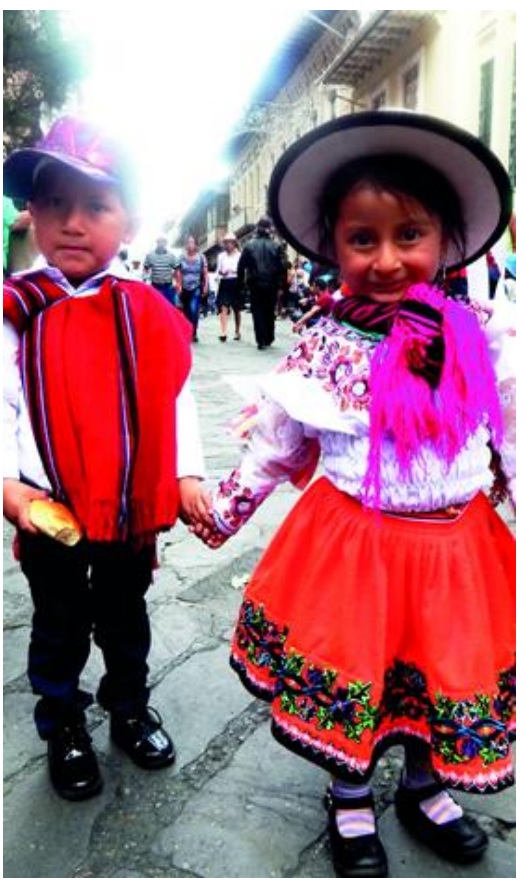

(b)

Figure 8. Traditional clothing of the Chola Cuencana (a) Women; (b) Children. Source: Authors elaboration

The Chola Cuencana bases its economy on productive and commercial activities. It is part of the intangible heritage of Cuenca and is part of the local culture. In everyday life, the Chola Cuencana plays an important role in the dynamics of the exterior spaces of the historic center; it makes visible the history and miscegenation; and seeing them walk through the cobbled streets gives a unique and characteristic touch to the city, which makes it stand out from other cities in Ecuador. The squares and parks of the historic center exhibit social encounters between the different ethnic groups in the city. In Calderón Park, there are optional and necessary activities that trigger social encounters of different intensity.

The Plaza de las Flores is an important benchmark for local social cohesion since its dynamics revolves around commerce, generates interaction between the Chola Cuencana, students, housewives, and tourists who come to the square. Furthermore, next to this square is the Carmen de la Asunción Church. Rotary Plaza presents a traditional character attractive to citizens and tourists, the Chola Cuencana is the protagonist because, every day, exhibits and sells products like woven baskets, reed mats, baskets, among others; wood handmade products such as chairs, cutting boards, drawers, spoons; pots, vases and more pottery articles. Figure 9, an example of social gatherings seen in the Plaza de las Flores and the Plaza Rotary. 


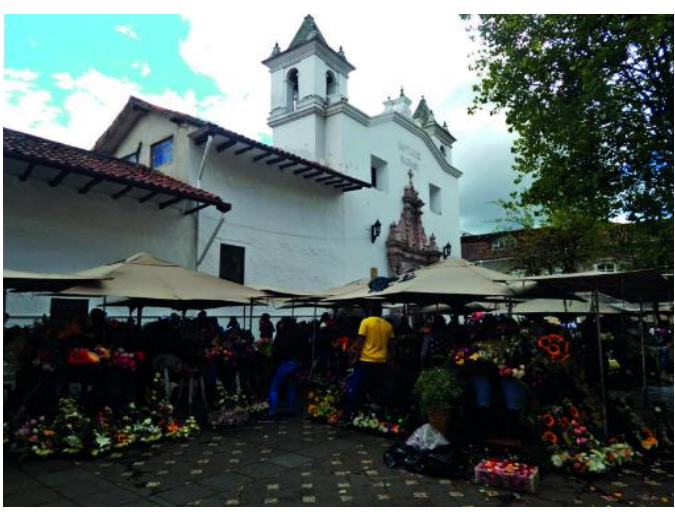

(a)

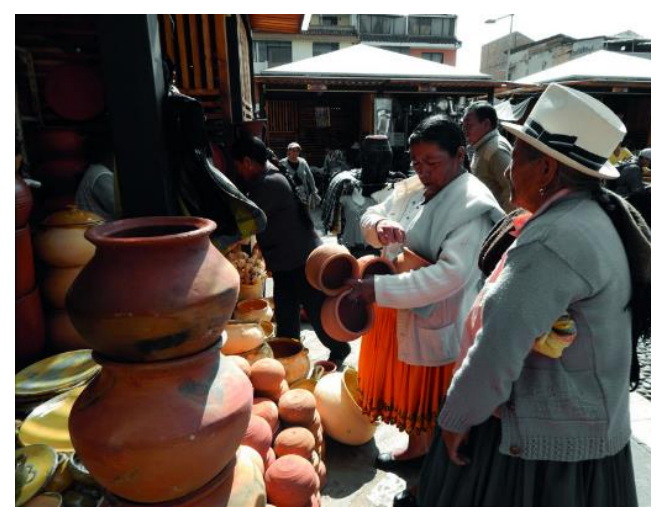

(b)

Figure 9. a) Social activity in the Plaza de las Flores; b) social activity at Plaza Rotary.

Source: Authors elaboration

The festivities are a very important cultural and social space due to traditions rooted in local culture and tradition; therefore, they constitute part of the intangible heritage of the city. In the festivities, the events of social cohesion are much more evident. Some of the events taking place throughout the year and set in the historic center are:

- $\quad$ The innocents parade (January 6);

- $\quad$ Thursday for Godfathers and Godmothers (Carnival Thursday);

- $\quad$ Corpus Christi (July, religious holiday);

- $\quad$ The Traveler Little Lord Jesus Pageant (December 24, religious holiday).

These events generate a large influx of people and bring a true celebration to the streets, full of color, tradition, and culture. The local festivities gather all the citizens, both mestizos with traditional clothing or not, people from all social classes (children, elders, senior citizens, young people, tourists) on the squares and on streets of the historic center and its surroundings.

\section{Data collection}

To know the social behavior of the pedestrian people from Cuenca in the five strategic points defined for this research, the interview, and direct observation are established as primary sources of information.

\section{Direct observation}

According to the (Golicnik and Ward Thompson 2010) methodology, direct observation was divided into four schedules at each of the five strategic points. The schedules were: 
- 08:00: Start activities of labor, student, commercial and banking, etc;

- 14:00: Lunchtime;

- 18:00: Completion of work activities, student, commercial and banking, etc;

- 21:00: Nighttime leisure activities.

Data collection, including weekends, took place in two weeks for six days, and the observation time at each strategic point was ten minutes per time slot. Observations studied mainly age, sex, nationality, type of activity people were doing, and location of people on the stairway. This last one was studied to associate with additional situations such as pedestrian preferences regarding sites of mobility (edge/center) and the direction of the routes (up / down). During the time of the observation, 3,337 pedestrians were identified, and out of this number, only 607 carried out a social activity.

\section{Interview}

In order to know the main motivations for walking along the stairway, two inter-views were conducted at each strategic point for each schedule during the six days. In total, 240 interviews were conducted. The questions that were asked to the users of stairways were as follows:

- What is the main reason for using the stairway?

- What are the reasons to avoid using the stairway?

- What activity or services would motivate you to stay on the stairway?

\section{Results}

Once the data collected from direct observation and interviews was processed, the following results were found.

\section{Motivation and demotivation for touring along the stairway}

The main reasons for touring along the stairway are associated with the use of nearby equipment or activities and/or services offered. For example, on the "Juana de Oro" stairway, users visit the murals; or on the stairway "Puente Roto" they prefer tourist photographs. The causes for demotivation are related to the insecurity and in-convenience associated with the high vehicular traffic in the area. Finally, users ex-pressed the need to generate actions aimed at the security and surveillance of the stairs, as well as the implementation of activities related to the gastronomic, artisanal, or recreational trade. Figure 10, motivation and demotivation for touring along the stairsways. There are also the main activities carried out at each strategic point. 


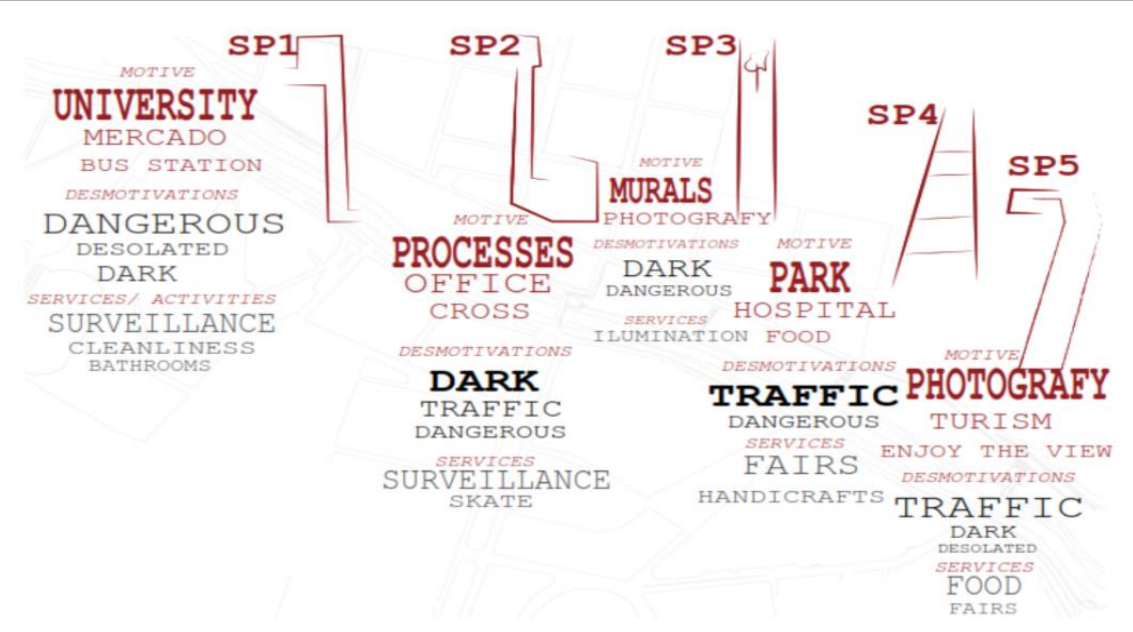

Figure 10. Motivation and demotivation to transit on the stairways.

Source: Authors elaboration

\section{Socio-spatial cohesion}

Regarding socio-spatial cohesion in "El Barranco", the results indicate that there is segregation by age. In figure 10 (a), the age group that makes the most use of public space is adults (64\%), followed by older adults (26\%) and, finally, children (10\%); this occurs in each of the study points. An important aspect to consider is that at strategic point SP 4, older adults are the ones who make the most use of public spaces, even though the spatial design of this stairway is not appropriate for this age group. If a nationality analysis is made, the results show that $80 \%$ of the users are Ecuadorian and $20 \%$ are foreigners. It is important to note that the La Chola Cuencana ethnic group constitutes $19 \%$ of the national users, this percentage is representative in the strategic points SP 1 and SP 2 where there is proximity to the market (figure $10(\mathrm{~b})$ ).

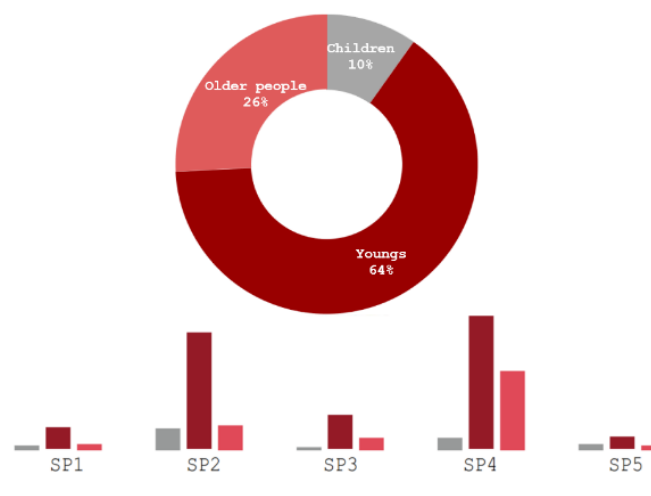

(a)

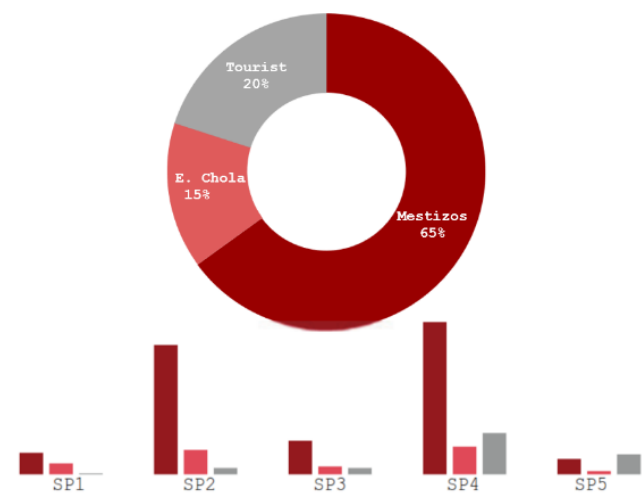

(b)

Figure 11. Spatial cohesion in "El Barranco" (a) Spatial cohesion by age group, (b) Spatial cohesion by nationality.

Source: Authors elaboration 


\section{Activities and pedestrian dynamics}

Regarding the type of activities that take place in "El Barranco" and according to the classification of (Soni and Soni 2016), it was obtained that $56 \%$ of the activities are necessary, $24 \%$ are optional and $20 \%$ are social. The figure 11 shows that the most popular strategic point is SP 4, this occurs due to the presence of hospitals, museums, the Faculty of Medicine of Cuenca's University, and the "Parque de la Madre", and it indicates that is a very important connecting point with the Historic Center of Cuenca.

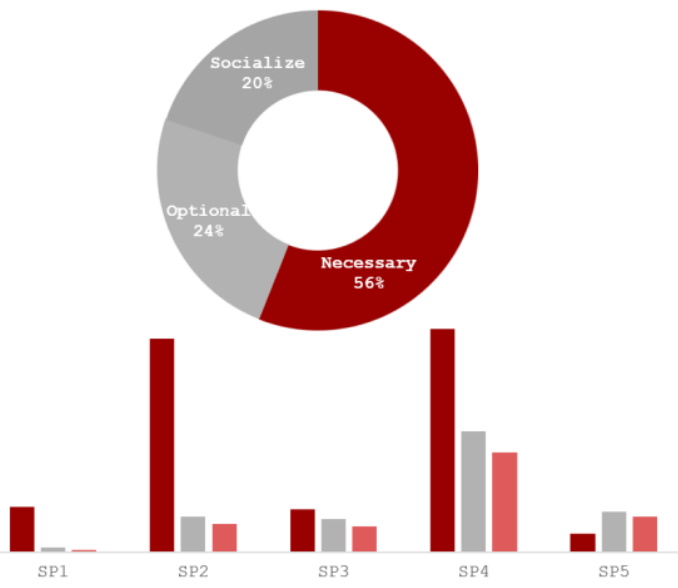

Figure 12. Type of activities that take place in "El Barranco".

Source: Authors elaboration

To know the dynamics of pedestrian users of "El Barranco", it was analyzed the influx of people in each of the strategic points according to the days of the week and times. Figure 12.
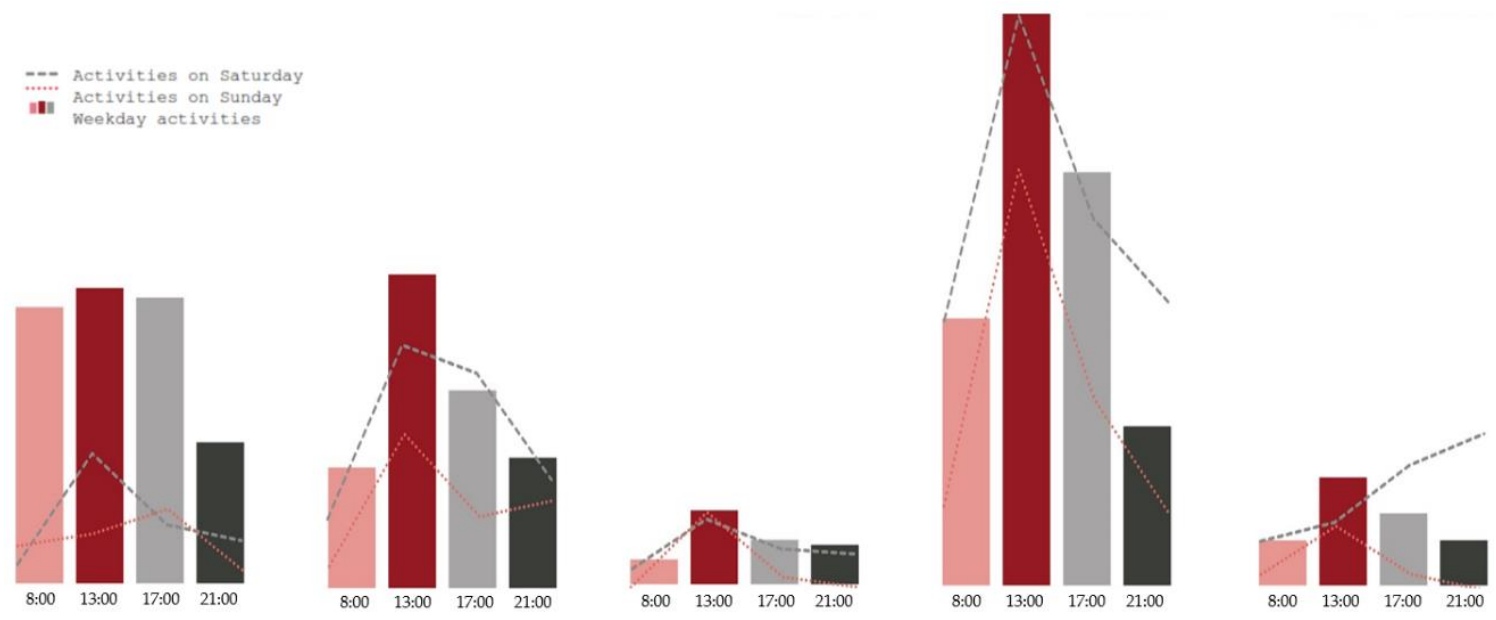

Figure 13. Pedestrian dynamics in "El Barranco"

Source: Authors elaboration 
SP 1: The major influx of people was from Monday to Friday. Sunday was the one with the least attendance due to the little university traffic. Also, users said that is a desolate place. Therefore, an urban intervention should be made in order to attract some pedestrian flow.

SP 2: Pedestrian flows on weekends were slightly lower than on weekdays. On Saturday afternoons, the influx of people increased due to the presence of young people in the park who carry out sports and recreation activities.

SP 3: It was the connection point with the least influx. However, from Monday to Friday, at noon, there was a greater movement of people. In the morning and at night on Sunday, the activities were significantly reduced, an intervention should be done on this area so users can change their perception and, therefore, a better use of this stairway can be done.

SP 4: "El Barranco" was the connection point with more activities, which makes a point of great influx of people. Activities increased considerably on Saturday nights, which goes hand in hand with the nightlife of the sector. On the other hand, sports activities were observed on Sundays.

SP 5: From Monday to Friday it presented a reduced number of activities, but in the afternoon and evening on Saturdays the social activities increased widely and with it, there was an important pedestrian dynamic. This is associated with the importance of the "Broken Bridge" as a landmark of Cuenca.

\section{Directionality, preference of the place of mobility and type of displacement}

In this Table 1, the directionality (if the pedestrian goes up or down the staircase), the preference of the places of pedestrian mobility on the staircase (traffic along the edge or through the center), and the type of pedestrian movement (alone or in a group).

Table 1. Directionality, preference of the place of mobility and type of movement at strategic points.

\begin{tabular}{lllllll}
\hline $\begin{array}{l}\text { Strategy } \\
\text { point }\end{array}$ & Up & Down & Border & Center & Alone & Group \\
\hline SP1 & 15 & 4 & 13 & 6 & 8 & 11 \\
SP2 & 46 & 44 & 70 & 20 & 53 & 37 \\
SP3 & 8 & 9 & 7 & 10 & 9 & 8 \\
SP4 & 37 & 55 & 52 & 40 & 54 & 37 \\
SP5 & 5 & 3 & 6 & 2 & 5 & 3 \\
\hline
\end{tabular}




\begin{tabular}{lcccccc}
\hline Total & 111 & 115 & 148 & 78 & 129 & 96 \\
$\begin{array}{l}\text { Percent } \\
(\%)\end{array}$ & 49.1 & 50.9 & 65.5 & 34.5 & 57.3 & 42.7 \\
\hline
\end{tabular}

As for directionality, it is concluded that most of the pedestrians walked down the stairway, this means that there were more people heading towards the area of new urban planning. Regarding the pedestrian's preference of places of mobility on the stairway, going around the edges was their answer. Finally, pedestrians preferred to travel alone rather than accompanied.

\section{Pedestrian behavior patterns in social activities}

Although few social activities take place in the strategic point SP 1, Figure 13 shows that most of the activities were conducted in the upper break which takes to the Condamine Street. The main social activities that were identified were appreciation of the environment and conversations. The edge towards "El Barranco" was the favorite one. It was also determined that the performance of social activities was associated with the adaptations of the staircase that allowed the improvement of its environment. Additionally, it was concluded that most of the social activities were carried out during the week; and that social activities at night are almost null, especially on weekends. The analysis of the behavior patterns at strategic point SP 2 indicated that social activities were mostly carried out on the edges and that the edge that was chosen most frequently is the one that faces the river; space stay 1 was not used for social activities then, the same as the green area, did not allow the performance of these activities. In addition, it was analyzed that the social activities that were carried out were spontaneous and arose at the time of walking down the stairs. It was also identified that during the weekend some activities were conducted in the stay 2 area due to young people meet there for skating. At noon, more stays of a social nature were detected, which is not the case at strategic point SP 1, where the largest number of social stays were made at night.

At strategic point SP3, social activities were held mostly from noon to afternoon. The social activities took place on the edge and were related to the presence of murals on the walls of the Hotel Crespo. The presence of trees caused activation of this space, which has generated some social activities such as conversations, family photographs, observation of the landscape, etc. At night, most of the activities took place at the top, towards Larga street. The appearance of fast-food sales and the absence of people on the stairways have caused 
pedestrians' perception of insecurity. Finally, the presence of access to the edges did not generate social activities.

On the stairway of strategic point SP 4, social activities were performed uniformly throughout the day, during the week. On Sundays, a lower percentage of activities were observed, mainly at night. Regarding the preference of the places of pedestrian mobility on the stairway, it was identified that the edges were chosen. Towards Larga street, there are vendors. Also, in the morning herbal teas are sold as well as local snacks or fruit; at night, shish kebab is offered as well as typical foods; the above makes this place an attraction for conducting social activities.

In general, the social activities carried out at point SP 5 were scarce. However, most of them were social ones and they are connected to the historical importance of the "Puente Roto" (Broken Bridge). This has become one of the favorite places of tourists. Stays at this stairway are used for talking, taking pictures, looking at the environment of the bridge, etc. The lower plaza does not generate social activities, but since there is a place for nightlife, the place is used as vehicle parking. In this sense, this analysis coincides with the interviews when describing this place as desolated. Figure 13 pedestrian behavior patterns are shown in social activities in five strategic points "El Barranco".

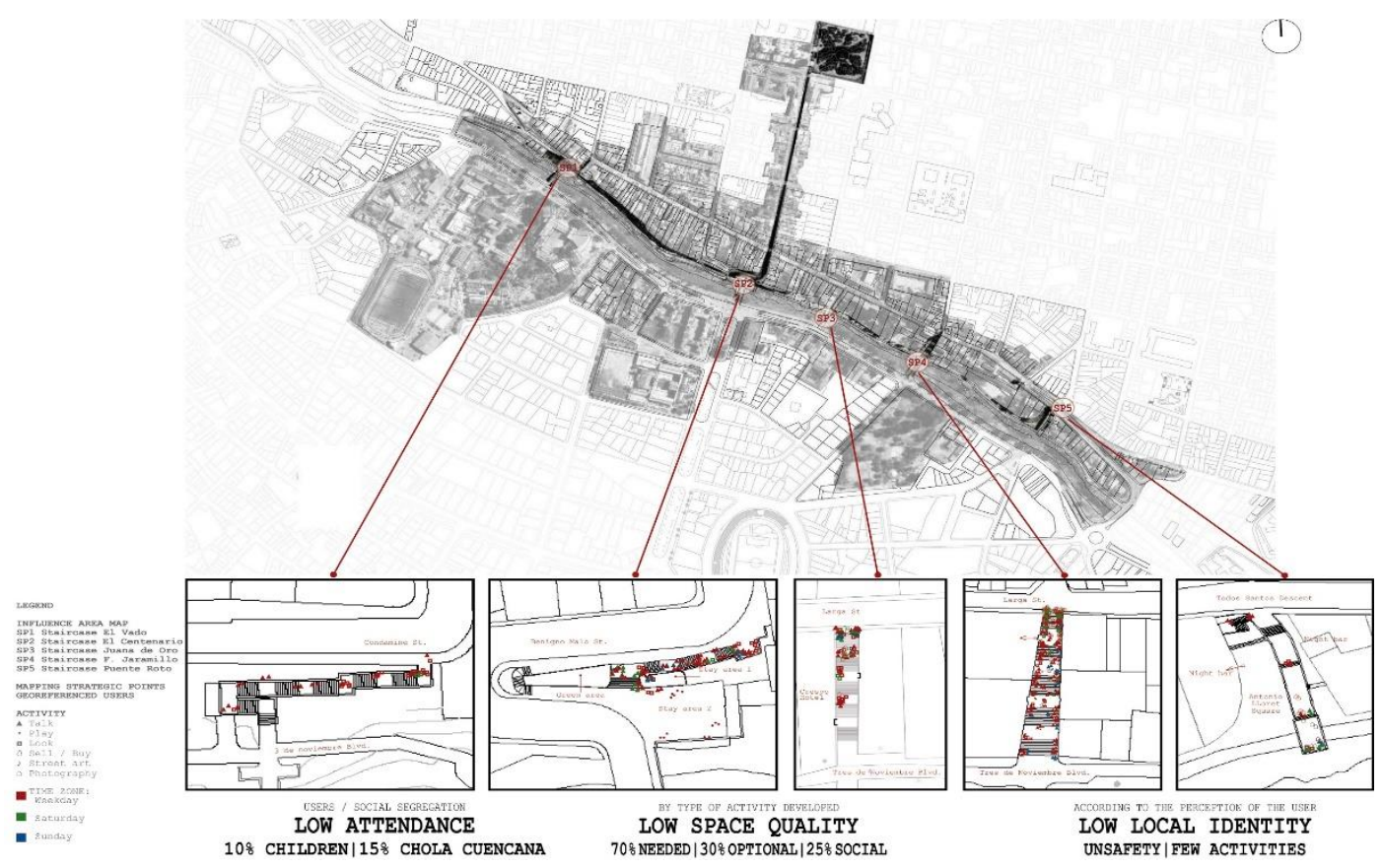

Figure 14. Pedestrian behavior patterns are shown in social activities in five strategic points "El Barranco".

Source: Authors elaboration

\section{Conclusion and Discussion}


- The principal finding of this research is the influence of the age group on the use of public space. For example, there was little presence of children in all strategic points. This goes hand in hand with what is suggested by (Karsten 2006) regarding that, the children have always constituted a significant part of the urban population and still do so today and therefore, it is important to reclaim the street as an area for urban livability for children. Therefore, the use of public space in most of the age groups constitutes a challenge for urban planners and designers.

- Another important finding has to do with the motivations of pedestrians to walk along the stairways, it became clear that, despite their inadequate spatial design, pedestrians needed to use them to access nearby equipment and/or necessary services. For example, a strategic point 4 , the senior citizen are the ones who mainly used the stairway to reach hospitals or parks. Regarding nationality, it was evidenced that this is related to the use of public space, since, on certain stairways, there was a significant number of foreign tourists. As for ethnicity, it is a fact that the "Chola Cuencana" is and will be an important element in the use of public space; first, because it is part of the intrinsic heritage wealth of the city and second because they generate necessary and optional activities that give rise to social encounters. However, at this point, efficient management of tourist activity is necessary since as mentioned (Haider 2007), poor management deteriorates the urban form on several scales, which could generate visual pollution, and that there are only globalization landscapes in a banal dimension.

- Considering the type of activity developed at strategic points, it was determined that most of the activities were necessary, this can be understood by the strategic location of the study area and the existence of important equipment on the terraces of the historic center and the new planning area. This test the hypothesis of Gehl concerning these activities that end up happening regardless of the physical aspect of the environment in which they develop, and their paths cannot be avoided (Gehl 2004).

- Another factor that confirms this hypothesis was the number of users who went up and down the stairways, as it was found that most users go down the stairs to go to the new planning area. However, if it is considered that the necessary activities play an important role in the daily lives of users of the city should ensure accessibility to public spaces, on this (Haider 2007) stated that the design is inclusive and intergenerational because "Fosters a sense of community participation of all stakeholders". And the urban area of Cuenca has low levels of accessibility for people with reduced mobility (Bustos-Piedra, M. Elisa; Marín-Palacios, Orellana, and Cabrera 2017).

- In the same line, it was found that only $24 \%$ of the activities were optional, this is directly related to the low quality of spatial design at strategic points. It was also established that, in general, activities of this type were carried out on the edges, and that people remained standing or leaned against some improvised element of the environment. These differences between necessary and optional activities could be explained by the statement (Carmona 2019) that says "public spaces take on different flavors as a result of the different groups of interests that create them and the particular range of uses they accommodate". Consequently, it is confirmed that the design of the public space of Cuenca is poor and a lot of work must be done to improve it and favor various users so they can develop a variety of activities, 
including social activities. In this re-search, social activities just reached $20 \%$ of all activities performed.

- Finally, it is important to understand the potential of "El Barranco" where the Tomebamba River is a vital element and that gives meaning to the five strategic points. In this sense, this study constitutes an opportunity to analyze the contemporary collective space system in contrast to the historic city. Also, the results presented provide guidelines for future interventions for public spaces designed for citizens.

\section{References}

Bustos-Piedra, M. Elisa; Marín-Palacios, Mateo, Daniel Orellana, and Natasha Cabrera. 2017. "Accesibilidad En El Espacio Público Para Personas Con Movilidad Reducida, Cuenca Como Caso de Estudio." In MEMORIAS V CONGRESO REDU, ed. Mauricio Espinoza. Cuenca.

Carmona, Matthew. 2019. "Principles for Public Space Design, Planning to Do Better." URBAN DESIGN International 24(1): 47-59. https://doi.org/10.1057/s41289-0180070-3.

Delgado, Manuel. 2004. "De La Ciudad Concebida a La Ciudad Practicada.” Archipiélago: Cuadernos de crítica de la cultura. (0214-2686): 7-12. https://www.academia.edu/33482488/De_la_ciudad_concebida_a_la_ciudad_practi cada?auto=download (July 8, 2018).

Gamboa, Pablo. 2002. "El Sentido Urbano Del Espacio Público.” Revista Bitácora Urbano Territorial (0124-7913): 13-18. https://bit.ly/2J5mhHg.

Gehl, Jan. 2004. LA HUMANIZACIÓN DEL ESPACIO URBANO: La Vida Social Entre Los Edificios. 5th ed. Copenhague: EDITORIAL REVERTE, S.A. https://kupdf.com/queue/gehl-jan-2006-la-humanizacion-del-espaciourbano_58e54dc6dc0d60f027da9828_pdf?queue_id=-1 (November 13, 2017).

Gehl, Jan 2014. Ciudades Para La Gente. 1a ed. Ciudad Autónoma de Buenos Aires: Ediciones Infinito. http://cisav.mx/wp-content/uploads/2017/03/M4T3.-Gehl-JanCiudades-para-la-gente-cap.-1.pdf (November 13, 2017).

Golicnik, Barbara, and Ward Ward Thompson. 2010. "Emerging Relationships between Design and Use of Urban Park Spaces.” Landscape and Urban Planning 94(01692046): 38-53.

https://www.sciencebase.gov/catalog/item/5057afa9e4b01ad7e0289aad (December 13, 2017).

Haider, Jawaid. 2007. "Inclusive Design: Planning Public Urban Spaces for Children." Municipal Engineer 160(2): 83-88. 
Hermida, M. Augusta, Natasha Cabrera-Jara, P. Osorio, and Stephanie Cabrera. 2019. "Methodology for the Assessment of Connectivity and Comfort of Urban Rivers." Cities 95: 102376.

Karsten, Lia. 2006. "Children in the City: Reclaiming the Street 1." Children, Youth and Environments 16(1): 151-67.

Mantey, Dorota, and Wojciech Pokojski. 2020. "New Indicators of Spatial Chaos in the Context of the Need for Retrofitting Suburbs." Land 9(8): 1-20.

Panagopoulos, Thomas et al. 2018. "The Usage and Perception of Pedestrian and Cycling Streets on Residents'well-Being in Kalamaria, Greece.” Land 7(3).

Soni, Nikhil, and Neetishree Soni. 2016. "Benefits of Pedestrianization and Warrants to Pedestrianize an Area.” Land Use Policy 57(5): 139-50.

Terraza, Horacio, María Isabel Beltrán, and Verónica Orbea. 2014. Cuenca, Ciudad Sostenible. Quito, Ecuador. http://propone.net/cccv.ec/docs/cuenca-cuidadsostenible.pdf (January 18, 2018). 


\section{PARA CITAR EL ARTÍCULO INDEXADO.}

Cherrez Rodas, K. A., Larco Benítez, M. A., \& Llulluna Llumiquinga, F. R. (2021). Pedestrian behavior patterns in relation to the quality of public space on the edge of the Historic Center of Cuenca-Ecuador. ConcienciaDigital, 4(1.1), 176-197. https://doi.org/10.33262/concienciadigital.v4i1.1.1553

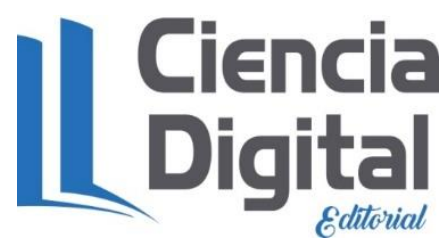

El artículo que se publica es de exclusiva responsabilidad de los autores y no necesariamente reflejan el pensamiento de la Revista Conciencia Digital.

El artículo queda en propiedad de la revista y, por tanto, su publicación parcial y/o total en otro medio tiene que ser autorizado por el director de la Revista Conciencia Digital.

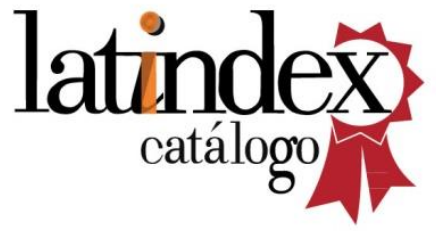

